九州大学学術情報リポジトリ

Kyushu University Institutional Repository

\title{
Long-term Application of Organic Residues to Improve Soil Properties and to Increase Crop Yield in Terrace Soil of Bangladesh
}

Karim, A.J.M. Sirajul

Laboratory of Soils, Faculty of Agriculture, Kyushu University

Egashira, Kazuhiko

Laboratory of Soils, Faculty of Agriculture, Kyushu University

Yamada, Yoshio

Emeritus Professor of Kyushu University; Former Team Leader of IPSA Project, JICA

Haider, Jamil

Department of Soil Science, IPSA (Institute of Postgraduate Studies in Agriculture)

他

https://doi.org/10.5109/24077

出版情報：九州大学大学院農学研究院紀要. 39 (3/4)，pp.149-165，1995-03. Kyushu University バージョン：

権利関係 : 


\title{
Long-term Application of Organic Residues to Improve Soil Properties and to Increase Crop Yield in Terrace Soil of Bangladesh
}

\section{A. J. M. Sirajul Karim, Kazuhiko Egashira, Yoshio Yamada*1, Jamil Haider ${ }^{* 2}$ and Kamrun Nahar*3}

\author{
Laboratory of Soils, Faculty of Agriculture, \\ Kyushu University, Fukuoka 812-81, Japan \\ (Received November 15, 1994)
}

\begin{abstract}
A field experiment was carried out from 1988 to 1993 at IPSA, Bangladesh, to evaluate the effects of long-term application of organic residues on the improvement of soil chemical and physical properties and on the increase in the crop yield. Five kinds of organic residues (no-application, rice straw, ipilipil leaves, compost, and cowdung) were applied every June to cover soil surface uniformly as a thin layer and incorporated into the soil to the depth of 10 $\mathrm{cm}$. Rice (July to October) and wheat (mid-November or December to March) were cultivated in rotation under the combination of five organic-residue treatments and three levels of inorganic $\mathrm{N}$ fertilizer.
\end{abstract}

The soil is terrace soil and was originally poor in chemical and physical properties. By application of organic residues, organic matter and total $\mathrm{N}$ contents of the surface layer were remarkably increased until nearly double. The soil increased in amount of available water by $50 \%$, became less compact and more porous, and increased in infiltration rate, although these improvements were limited to the ploughing depth of maximum $10 \mathrm{~cm}$. Among the organic residues, compost made of rice-straw and cowdung was the most effective to improve both chemical and physical properties. Rice straw tended to improve physical properties rather than chemical properties, while ipilipil leaves and cowdung were effective to the improvement of chemical properties.

Effect of application of organic residues on the increase in the crop yield was more distinct for rice than for wheat, because organic residues were applied just before transplantation of rice seedlings. Grain yield of rice increased with year and attained the maximum and stabilized state after 4th year from initiation of the experiment in which grain yield of more than $2.5 \mathrm{Mg} /$ ha was obtained under no-application of inorganic $\mathrm{N}$ fertilizer. With a combination of 75-100 kg/ha of $\mathrm{N}$ fertilizer, yield over $4 \mathrm{Mg} / \mathrm{ha}$ was expected. Among the organic residues, compost was the most effective, closely followed by ipilipil leaves and cowdung. Grain yield of wheat increased linearly with amount of $\mathrm{N}$ fertilizer applied in each year. Maximum grain yield was $3.5-4.0 \mathrm{Mg} / \mathrm{ha}$ under $120 \mathrm{~kg} / \mathrm{ha}$ of $\mathrm{N}$. Application of organic residues significantly increased grain yield of wheat. But, accumulation effect of organic residues on the yield was not observed and grain yield was still below $1.0 \mathrm{Mg} / \mathrm{ha}$ under no-N application even after 5 years of cultivation. Among the organic residues, compost brought about the highest grain yield.

Compost was concluded to be the most effective organic residue to improve soil chemical and physical properties under the crop rotation of rice and wheat in terrace soil. It was estimated for compost to increase the rice yield mostly through improvement of chemical properties and to contribute to increase in the wheat yield by improvement of physical properties.

*1 Emeritus Professor of Kyushu University; Former Team Leader of IPSA Project, JICA.

*2 Department of Soil Science, IPSA (Institute of Postgraduate Studies in Agriculture), Salna, Gazipur, Bangladesh.

*3 Department of Soil Science, IPSA, Bangladesh (present address : Analytical Services Division, Bangladesh Agricultural Research Institute, Joydebpur, Gazipur, Bangladesh). 


\section{INTRODUCTION}

In Bangladesh located mostly in the Ganges-Brahmaputra delta, floodplain soils occupy $80 \%$ of the national land. Terrace soils only occupy $8 \%$ of the total land, but the terrace soil area is densely populated because of its socio-economic and agroecological importance. The terrace soils were characterized by poor chemical and physical properties (Karim et al., 1994). They were depleted of organic matter and plant nutrients and suffered from high acidity and Al toxicity. In the surface horizon clay particles were replaced by sand or silt particles, thereby reducing the water holding capacity of the surface soil. The subsurface clayey horizons were so compact that internal drainage and root penetration of crops were seriously restricted. In addition, poor properties of the terrace soils have been worsened further due to the mismanagement by farmers. Nutrients harvested from the soil through cultivation of crops are not replenished by the regular addition of organic and inorganic fertilizers. Single crop is grown year by year without following any scientific rotation, leading to deficiency of specific nutritional elements.

Soil properties have been reported to be improved by the application of organic residues. Addition of organic residues improves soil structure and aeration by increasing soil porosity (Greenland, 1988). Field research at Rice Research Station of Himachal Pradesh Agricultural University, India, showed reduction of soil compaction, betterment of drainage condition, and increase in the contents of organic $\mathrm{C}$ and available $\mathrm{N}$ and $\mathrm{P}$ by application of farmyard manure (Ganai and Singh, 1988). This improvement resulted in increasing the yield of rice and wheat grains. In a field experiment in India, Sherma et al. (1988) found that application of organic residues significantly increased water holding capacity of soil and improved fertility status as well. Rabindra et al. (1985) informed that the combined application of organic residues and inorganic nitrogen fertilizer improved physical and chemical conditions and soil productivity but that use of nitrogen fertilizer alone for a long period caused deterioration of physical condition and organic matter status and reduced crop yield.

It is now essential to increase organic matter content through periodic addition of organic residues along with application of inorganic fertilizers for maintaining soil productivity to achieve maximum and stabilized crop yield in the terrace soil. In the present paper, a field research which was carried out at IPSA, Bangladesh, to elucidate the effects of long-term application of different types of organic residues on the improvement of soil chemical and physical properties and on the increase in the yield of rice and wheat grains is reported.

\section{MATERIALS AND METHODS}

\section{Location}

The field experiment was initiated in March, 1988 at the experimental farm of IPSA (Institute of Postgraduate Studies in Agriculture), Salna, Gazipur, Bangladesh. It is located in the centre of the Madhupur tract (24" $\left.05^{\prime} \mathrm{N}, 900^{\prime} 16^{\prime} \mathrm{E}\right)$ at $8.4 \mathrm{~m}$ above sea level and about $40 \mathrm{~km}$ north of Dhaka, the capital of Bangladesh. The land 
naturally had undulated topography and was covered by sal forest. It was deforestated about 5 years before initiation of the experiment and then levelled to develop the experimental farm.

\section{Experimental design and cropping schedule}

The experiment was laid out in $5 \times 3$ factorial design with four replications. Five treatments of organic residues and three treatments of nitrogen fertilizer were arranged randomly in each replication. The dimension of each plot was $12 \mathrm{~m} \mathrm{x} 7 \mathrm{~m}$ having a plot-to-plot distance of $1.5 \mathrm{~m}$.

The cropping schedule along with the time of application of organic residues and soil sampling is presented in Table 1. Rice and wheat were cultivated in rotation as the kharif and rabi crops, respectively. High-yielding variety of T. aman 'BR 14' was used and transplanted within July every year and harvested in October. 'Akbar', high -yielding variety of wheat, was sown between mid-November and December and harvested in March in each year. Until October, 1993, rice and wheat were grown 6 and 5 times, respectively.

Organic residues were applied to the soil once (June) in every year at 20-25 days before transplantation of rice. This timing of application was determined to ensure rapid decomposition of organic residues according to the recommendation of the scientist of Bangladesh Rice Research Institute. Soil sampling was done in the rabi season except 1988 and 1989, because the rabi season was convenient to collect undisturbed soil samples and to conduct infiltration measurement of water in the field under unsaturated soil moisture condition.

\section{Application of organic residues}

Five kinds of organic residues were applied as follows :

Mo : no application of organic residues ;

Rs : air-dry rice straw at the rate of $2.0 \mathrm{Mg} / \mathrm{ha}$;

$\mathrm{Gm}$ : fresh ipilipil leaves as green manure at the rate of $7.5 \mathrm{Mg} / \mathrm{ha}$;

cp : compost at the rate of $25 \mathrm{Mg} / \mathrm{ha}$. Compost was made of rice straw and cowdung that were kept in successive layers of $15 \mathrm{~cm}$ in a pit of $1.5 \mathrm{~m}$ deep and allowed to rotten for 100 to 120 days ;

$\mathrm{Cd}$ : fresh cowdung at the rate of $25 \mathrm{Mg} / \mathrm{ha}$.

Rates of application of organic residues were determined to ensure their uniform distribution as a thin layer over the soil surface. Organic residues were then incorpo-

Table 1. Cropping schedules and time of application of organic residues and soil sampling.

\begin{tabular}{|c|c|c|c|c|c|}
\hline \multirow{2}{*}{$\begin{array}{c}\text { Soil } \\
\text { sampling }\end{array}$} & \multirow{2}{*}{$\begin{array}{l}\text { Application of } \\
\text { organic residues }\end{array}$} & \multicolumn{2}{|c|}{ Rice cultivation } & \multicolumn{2}{|c|}{ Wheat cultivation } \\
\hline & & Transplantation & Harvest & Sowing & Harvest \\
\hline 6, 1988 & Jun. 15,1988 & Jul. 8,1988 & Oct. 4, 1988 & Nov. 26, 1988 & Mar. 3, 1989 \\
\hline May 5, 1989 & Jun. 23, 1989 & Jul. 15,1989 & Oct. 17,1989 & Dec. 15,1989 & Mar. 18,1990 \\
\hline Feb. 2, 1990 & Jun. 27, 1990 & Jul. 18,1990 & Oct. 22, 1990 & Dec. 16,1990 & Mar. 22, 1991 \\
\hline Feb. 18, 1991 & Jun. 20, 1991 & Jul. 12, 1991 & Oct. 16, 1991 & Nov. 26, 1991 & Mar. 9, 1992 \\
\hline Mar. 10, 1992 & Jun. 24, 1992 & Jul. 14, 1992 & Oct. 13, 1992 & Nov. 24, 1992 & Mar. 13, 1993 \\
\hline Feb. 10, 1993 & Jun. 13, 1993 & Jul. 4, 1993 & Oct. 11, 1993 & & - \\
\hline
\end{tabular}


rated into the soil by power tiller to the maximum depth of $10 \mathrm{~cm}$.

\section{Fertilizer application}

Three levels of $\mathrm{N}$ were applied in the form of urea for both the crops. For rice the rate of application was 0,75 , and $100 \mathrm{~kg} / \mathrm{ha}$ as $\mathrm{N}$, and for wheat it was 0,80 , and $120 \mathrm{~kg} / \mathrm{ha}$ as $\mathrm{N}$. The three levels of $\mathrm{N}$ were designated as NO, N1, and N2 treatments in the increasing rate of application for both rice and wheat. One-third of total $\mathrm{N}$ in rice and half of total $\mathrm{N}$ in wheat were applied at final land preparation as basal application. The rest of $\mathrm{N}$ was top-dressed in two equal splits at 20 to 25 days and at 50 to 55 days after transplanting of rice or sowing of wheat.

Triple superphosphate (TSP) and muriate of potash (MP) were applied to each plot at final land preparation to supply $\mathrm{P}$ and $\mathrm{K}$, respectively. TSP was applied at the rate of $100 \mathrm{~kg} / \mathrm{ha}$ as $\mathrm{P}_{2} \mathrm{O}_{5}$ for both the crops, and MP was applied at the rates of 80 and 60 $\mathrm{kg} / \mathrm{ha}$ as $\mathrm{K}_{2} \mathrm{O}$ for rice and wheat, respectively.

\section{Cultivation practice}

The land for rice cultivation was ploughed by power tiller after wetting the soil by water. Bullocks-drawn wooden plough and ladder were used for puddling and levelling the soil. Thirty-five- to 40-day-old seedlings were transplanted at the rate of 3 to 4 seedlings per hill keeping a row-to-row spacing of $25 \mathrm{~cm}$ and a hill-to-hill spacing of $20 \mathrm{~cm}$. Two times of weeding were required : one at 20 to 25 days and the other at 40 to 45 days after transplantation of seedlings. No irrigation was required, but whenever the rainy season ceased early in September one irrigation was required.

The land preparation for wheat cultivation was rather difficult and time-consuming. This was due to high clay content which created difficulty in attaining optimum soil moisture condition at land preparation. The soil was essential to attain the field capacity at the start of ploughing. The land was first opened by tractor-driven mould -board plough followed by harrowing. After final land preparation wheat seeds were sown in lines at the rate of $120 \mathrm{~kg} / \mathrm{ha}$ keeping a row-to-row distance of $20 \mathrm{~cm}$. Weeding, thinning of wheat seedlings, and loosening of soil were done only once at 20 to 25 days after sowing of seeds. Three to 4 irrigations were required every year to fulfill the water requirement of wheat.

\section{Collection of soil samples}

Soil samples were collected from different treatments of organic residues under NO treatment to represent most distinctly the impact of organic residues on soil properties. Samples were collected from four random spots of individual plots at three different depths of O-5, 10-15, and 20-25 cm. Random sampling was done to minimize the effect of heterogeneity in soil. Soil sampling was done at one out of four replications due to lack of facilities.

\section{Methods of soil analyses}

Soil $\mathrm{pH}$ was determined by glass electrode as described by Jackson (1958). Organic carbon was determined by the wet combustion method as outlined by Piper (1942). The Kjeldahl method was used for the determination of total N (Bremner, 1965). Particle-size analysis was carried out by the hydrometer method (Bouyoucos, 
1927). The soil moisture at field capacity was determined by the field method (Karim et $\boldsymbol{a l}$., 1988). The soil moisture at pF 4.2 (wilting point) was determined by using a pressure plate apparatus at Bangladesh Agricultural Research Institute. The bulk density was determined by taking undisturbed soil sample in a core sampler of $100 \mathrm{~cm}^{3}$ in volume. Pycnometer method was used for determining particle density of soil (Blake, 1965). Soil water infiltration was determined in the field by using a double -ring cylinder infiltrometer. Saturated hydraulic conductivity was measured by the falling-head method in the laboratory. Detailed analytical methods were described in the previous paper (Karim et al., 1994).

\section{Statistical analysis of grain yield}

Duncan's multiple range test was used for statistical analysis of grain yield.

\section{RESULTS AND DISCUSSION}

\section{Properties of the original soil}

Selected chemical and physical properties of the original soil are presented in Table 2. The soil was collected for analysis on April 6, 1988. The pH was 5.6 in the surface $(\mathrm{O}-5 \mathrm{~cm})$ and 5.3 in the bottom $(20-25 \mathrm{~cm})$ layer. The organic matter and total $\mathrm{N}$ contents in the surface layer were as low as 7.2 and $0.30 \mathrm{~g} / \mathrm{kg}$, respectively, indicating the poor fertility status. The soil was silty clay loam in texture at three depths having high clay and silt contents of 380 to $400 \mathrm{~g} / \mathrm{kg}$ and 450 to $480 \mathrm{~g} / \mathrm{kg}$, respectively. The soil was compact all through the three depths having very high solid phase of 56 to $68 \%$ by volume with the higher bulk density of 1.46 to $1.77 \mathrm{~g} / \mathrm{cm}^{3}$. Below $10 \mathrm{~cm}$ depth the pore space was mostly occupied by water indicating anaerobic condition of the soil.

\section{Chemical properties of soil \\ O rganic matter content}

Organic matter content of the soils applied by different kinds of organic residues is presented in Table 3. Application of organic residues has resulted in increasing the organic matter content of the soils, but the increase was not gradual and rather inconsistent values were obtained in different years. For this reason the organic matter content in the surface layer was averaged to evaluate the accumulation of organic matter in the treated soils. In average of five years, the highest content of organic matter was recorded in Cp plot $(13.3 \mathrm{~g} / \mathrm{kg})$ which was $48 \%$ higher than that in Mo $(9.0 \mathrm{~g} / \mathrm{kg})$ plot. The values as recorded in Cd, Rs, and Gm plots were 12.0,11.2, and

Table 2. Selected chemical and physical properties of the soil before experiment.

\begin{tabular}{|c|c|c|c|c|c|c|c|c|c|c|c|}
\hline \multirow{2}{*}{$\begin{array}{l}\text { Soil depth } \\
\text { (cm) }\end{array}$} & \multirow{2}{*}{ Soil $\mathrm{pH}$} & \multirow{2}{*}{$\begin{array}{c}\text { Organic matter } \\
(\mathrm{g} / \mathrm{kg})\end{array}$} & \multicolumn{2}{|c|}{ Total N Particle-size } & \multirow{2}{*}{$\begin{array}{l}\text { distribution } \\
\text { Slit }\end{array}$} & \multirow{2}{*}{$\begin{array}{l}(\mathrm{g} / \mathrm{kg}) \\
\text { Sand }\end{array}$} & \multirow{2}{*}{$\begin{array}{c}\text { Soil } \\
\text { texture }\end{array}$} & \multirow{2}{*}{$\begin{array}{l}\text { Bulk density } \\
(\mathrm{g} / \mathrm{cm} ")\end{array}$} & \multicolumn{3}{|c|}{ Three-phase distribution (vol. \%) } \\
\hline & & & $(\mathrm{g} / \mathrm{kg})$ & Clay & & & & & Solid & Liquid & Gas \\
\hline $0-5$ & 5.6 & 7.2 & 0.30 & 400 & 470 & 130 & $\mathrm{SiC}-\mathrm{SiCL}$ & 1.46 & 56.4 & 19.6 & 24.0 \\
\hline $10-15$ & 5.4 & 6.6 & 0.25 & 380 & 450 & 170 & $\mathrm{SiCL}$ & 1.77 & 68.3 & 29.2 & 2.5 \\
\hline $20-25$ & 5.3 & 4.7 & 0.25 & 380 & 480 & 140 & $\mathrm{SiCL}$ & 1.69 & 63.1 & 36.9 & trace \\
\hline
\end{tabular}


$10.9 \mathrm{~g} / \mathrm{kg}$, respectively, and 33, 24, and $21 \%$ higher than that in Mo plot. In Mo plot there was an increase in $25 \%$ of organic matter compared with the original soil which may have come from crop roots and residues.

For evaluating the fate of organic matter at different period of the year after the application of organic residues, bimonthly monitoring of organic matter content of the surface layer was carried out from October, 1992 to August, 1993, in the fifth year of the experiment. The data is presented in Table 4. In October the organic matter content of the soil of different treatments reflected the application of organic residues showing the values of 10.7, 12.8, 12.2, 14.6, and $16.4 \mathrm{~g} / \mathrm{kg}$ in Mo, Rs, Gm, Cp, and Cd plots, respectively. But, with the time the organic matter decreased quickly and came down finally to the minimum and similar values of $9.8,9.1,9.6,9.1$, and $10.3 \mathrm{~g} / \mathrm{kg}$ in the respective plots in June, 1993, followed by the increase in organic matter content by another application of organic residues. At the end of the year applied organic residues were almost all exhausted from the soil. It may indicate that organic matter accumulates in equilibrium at the level of $9-10 \mathrm{~g} / \mathrm{kg}$ under the present application rate

Table 3. Annual change of organic matter content of the soil under application of different organic residues.

\begin{tabular}{|c|c|c|c|c|c|c|c|}
\hline \multirow{2}{*}{\multicolumn{2}{|c|}{$\begin{array}{l}\text { Treatment } \\
\& \text { depth }(\mathrm{cm})\end{array}$}} & \multicolumn{6}{|c|}{ Organic maiter $(\mathrm{g} / \mathrm{kg})$} \\
\hline & & \multicolumn{2}{|c|}{ May 1989 1Feb. 1990} & \multirow{2}{*}{$\begin{array}{c}\text { Feb. } 1991 \\
7.4\end{array}$} & \multirow{2}{*}{$\begin{array}{c}\text { Mar. } 1992 \\
9.3\end{array}$} & \multirow{2}{*}{\begin{tabular}{|c|} 
1Feb. 1993 \\
9.3
\end{tabular}} & \multirow{2}{*}{$\begin{array}{c}\text { Average } \\
9.0\end{array}$} \\
\hline Mo & $0-5$ & 9.0 & 10.2 & & & & \\
\hline & $10-15$ & 7.8 & 8.7 & 6.6 & 5.3 & 7.3 & \\
\hline & $20-25$ & 7.1 & 8.0 & 4.5 & 5.0 & 4.0 & \\
\hline Rs & $0-5$ & 10.6 & 12.1 & 11.2 & 10.7 & 11.2 & 11.2 \\
\hline & $10-15$ & 8.7 & 10.2 & 8.3 & 6.2 & 6.7 & \\
\hline & $20-25$ & 7.1 & 8.7 & 5.7 & 5.2 & 5.0 & \\
\hline $\mathrm{Gm}$ & $0-5$ & 11.2 & 13.0 & 10.0 & 9.9 & 10.3 & 10.9 \\
\hline & $10-15$ & 9.0 & 11.1 & 8.8 & 8.1 & 7.8 & \\
\hline & $20-25$ & 7.6 & 8.1 & 5.0 & 5.5 & 5.5 & \\
\hline $\mathrm{Cp}$ & $0-5$ & 11.8 & 14.4 & 11.4 & 16.3 & 12.4 & 13.3 \\
\hline & $10-15$ & 6.9 & 6.9 & 7.4 & 9.7 & 9.0 & \\
\hline & $20-25$ & 5.7 & 6.1 & 4.8 & 7.1 & 7.1 & \\
\hline $\mathrm{Cd}$ & $0-5$ & 10.0 & 11.1 & 12.6 & 13.3 & 13.1 & 12.0 \\
\hline & $10-15$ & 4.8 & 5.7 & 8.3 & 9.0 & 7.6 & \\
\hline & $20-25$ & 5.5 & 5.0 & 6.2 & 6.4 & 4.3 & \\
\hline
\end{tabular}

Table 4. Organic matter content of the surface soil at different period after application of organic residues.

\begin{tabular}{c|c|rc|ccc}
\hline & \multicolumn{5}{|c}{ Organic matter (g/kg) } \\
Treatment & Oct. 14,1992 & Dec. 15, 1992 Feb. 10, 1993 & Apr. 14, 1993 Jun. 5, 1993 & Aug. 8, 1993 \\
\hline Mo & 10.7 & 9.6 & 9.3 & 8.8 & 9.8 & 11.5 \\
Rs & 12.8 & 12.4 & 11.2 & 11.7 & 9.1 & 14.1 \\
Gm & 12.2 & 11.0 & 10.3 & 10.0 & 9.6 & 12.6 \\
Cp & 14.6 & 13.1 & 12.4 & 10.5 & 9.1 & 13.4 \\
Cd & 16.4 & 14.0 & 13.1 & 11.0 & 10.3 & 12.9 \\
\hline
\end{tabular}


of organic residues and that newly applied organic residues cause temporal increase in organic matter content until the level of $14-16 \mathrm{~g} / \mathrm{kg}$.

The climatic condition of this tropical country accelerates decomposition of organic matter, and the rates of application of organic residues used in the present study may not be sufficient to cause its further accumulation in the soil. Under this circumstance there are two options to solve the problem : (a) to increase the rate of application of organic residues for encouraging further accumulation of organic matter in soil, but it is a big problem for the poor farmers, or (b) to maintain the present rate of application every year and get the benefit of higher yield of crops as will be shown in rice and wheat yields later.

\section{Total nitrogen content}

Total $\mathrm{N}$ content of the soils is presented in Table 5. Applicaion of organic residues has caused increase in the total $\mathrm{N}$ content but like organic matter its increase in the succeeding years was not gradual. As such the data of five years was averaged for evaluating the impact of application of organic residues on increase of $\mathrm{N}$ content in soil. Among the organic residues, the highest total $\mathrm{N}$ content of $0.59 \mathrm{~g} / \mathrm{kg}$ was recorded in $\mathrm{Cp}$ plot which was $23 \%$ higher than the value of $0.48 \mathrm{~g} / \mathrm{kg}$ recorded in Mo plot. The total $\mathrm{N}$ contents in $\mathrm{Cd}$ and $\mathrm{Gm}$ plots were close to that in $\mathrm{Cp}$ plot having the values of 0.58 and $0.56 \mathrm{~g} / \mathrm{kg}$, respectively. The total $\mathrm{N}$ content in Rs plot, however, remained at the same level as that of Moplot. With respect to the total $\mathrm{N}$ content of the original soil it increased by $60,57,87,97$, and $93 \%$ in Mo, Rs, Gm, Cp, and $\mathrm{Cd}$ plots, respectively. Crop roots and residues may have contributed to increase in the $\mathrm{N}$ content in Mo plot.

For evaluation of the difference in the total $\mathrm{N}$ content between different plots, $\mathrm{N}$ contents of organic residues were analysed before application in 1993. They were

Table 5. Annual change of the total $\mathrm{N}$ content of the soil under application of different organic residues.

\begin{tabular}{|c|c|c|c|c|c|c|c|}
\hline \multirow{2}{*}{\multicolumn{2}{|c|}{$\begin{array}{l}\text { Treatment } \\
\& \text { depth }(\mathrm{cm})\end{array}$}} & \multicolumn{6}{|c|}{ Total N (g/kg) } \\
\hline & & May 1989 & |Feb. 1990 & Feb. 1991 & | Mar. 1992 & Feb. 1993 & Average \\
\hline \multirow[t]{3}{*}{ Mo } & $0-5$ & 0.41 & 0.44 & 0.45 & 0.53 & 0.59 & 0.48 \\
\hline & $10-15$ & 0.27 & 0.32 & 0.24 & 0.28 & 0.25 & \\
\hline & $20-25$ & 0.25 & 0.31 & 0.21 & 0.29 & 0.22 & \\
\hline \multirow[t]{3}{*}{ Rs } & $0-5$ & 0.37 & 0.36 & 0.39 & 0.60 & 0.65 & 0.47 \\
\hline & $10-15$ & 0.26 & 0.28 & 0.25 & 0.27 & 0.36 & \\
\hline & $20-25$ & 0.20 & 0.25 & 0.26 & 0.21 & 0.25 & \\
\hline \multicolumn{2}{|c|}{$\mathrm{Gm} \mathrm{0-5}$} & 0.51 & 0.54 & 0.53 & 0.50 & 0.70 & 0.56 \\
\hline & $10-15$ & 0.31 & 0.37 & 0.32 & 0.35 & 0.47 & \\
\hline & $20-25$ & 0.30 & 0.35 & 0.35 & 0.28 & 0.31 & \\
\hline \multirow[t]{3}{*}{$\mathrm{Cp}$} & $0-5$ & 0.45 & 0.51 & 0.48 & 0.90 & 0.61 & 0.59 \\
\hline & $10-15$ & 0.28 & 0.30 & 0.36 & 0.48 & 0.37 & \\
\hline & $20-25$ & 0.27 & 0.21 & 0.32 & 0.41 & 0.30 & \\
\hline \multirow[t]{3}{*}{$\mathrm{Cd}$} & $0-5$ & 0.47 & 0.49 & 0.51 & 0.71 & 0.72 & 0.58 \\
\hline & $10-15$ & 0.29 & 0.32 & 0.42 & 0.43 & 0.46 & \\
\hline & $20-25$ & 0.24 & 0.13 & 0.27 & 0.36 & 0.32 & \\
\hline
\end{tabular}


found to be $8.3,30.6,6.5$, and $11.1 \mathrm{~g} / \mathrm{kg}$ for rice straw, ipilipil leaves, compost, and cowdung, respecttively. By assuming water content as $15,50,25$, and $40 \%$ by weight in the respective order, amount of $\mathrm{N}$ which can be supplied to soil through organic -residue application was calculated to be 14, 115, 122, and $166 \mathrm{~kg} / \mathrm{ha}$ for Rs, Gm, Cp, and $\mathrm{Cd}$ plots, respectively. These values are rough estimates and $\mathrm{N}$ contents of organic residues may vary with year, but it at least explains the difference in the total $\mathrm{N}$ content between $\mathrm{Cp}, \mathrm{Cd}$, and $\mathrm{Gm}$ plots and Rs plot.

\section{Physical properties of soil}

\section{Moisture holding capacity}

Moisture holding capacity of the soils was evaluated by the determination of soil moisture at field capacity (FC) and at wilting point (WP) and by the calculation of soil available water (SAW) by subtracting soil moisture at WP from that at FC. The experimental results in 1991 and 1992 are shown in Table 6. The increase in organic matter content of soil favoured increasing the soil moisture at FC of the surface layer. It led to decreasing the soil moisture at WP as well and resulted in remarkable increase in SAW.

The SAW in the surface layer of Mo plot in 1991 and 1992 was 9.7 and $10.3 \%$ by weight, respectively, which is too low to attain higher water use efficiency for upland rabi crops. The highest SAW of 14.5 to $15.2 \%$ was recorded in Rs plot which was 49 to $48 \%$ higher than that recorded in Mo. The next higher SAW of 14.1 to $14.6 \%$ was recorded in $\mathrm{Cp}$ plot which was 45 to $42 \%$ higher than that in $\mathrm{M} \mathrm{O}$. In $\mathrm{Gm}$ and $\mathrm{Cd}$ plots the SAW was recorded to be 11.8 to 12.2 and 12.9 to $13.7 \%$, respectively, and it was less than those recorded in Rs and Cp plots. Incorporation of rice straw or compost to soil probably made the soil more porous and resulted in increasing the soil moisture at FC

Table 6. Moisture holding capacity (weight \%) of the soil under application of different organic residues.

\begin{tabular}{|c|c|c|c|c|c|c|c|}
\hline \multirow{3}{*}{\multicolumn{2}{|c|}{$\begin{array}{c}\text { Treatment } \\
\text { \& depth }(\mathrm{cm})\end{array}$}} & \multicolumn{3}{|c|}{ Feb. 1991} & \multicolumn{3}{|c|}{ Mar. 1992} \\
\hline & & \multirow{2}{*}{\multicolumn{2}{|c|}{$\begin{array}{c}\text { Soil moisture at } \\
\text { Geld capacity Wilting point }\end{array}$}} & \multirow{3}{*}{$\begin{array}{c}\begin{array}{c}\text { Available } \\
\text { water }\end{array} \\
9.7\end{array}$} & \multicolumn{2}{|c|}{ Soil moisture at } & \multirow{3}{*}{$\begin{array}{c}\begin{array}{c}\text { Available } \\
\text { water }\end{array} \\
10.3\end{array}$} \\
\hline & & & & & Field capacity & Wilting point & \\
\hline Mo & $0^{-5}$ & 27.4 & 17.7 & & 27.5 & 17.2 & \\
\hline & $10-15$ & 22.8 & 14.7 & 8.1 & 23.7 & 15.9 & 7.8 \\
\hline & $20-25$ & 23.3 & 15.5 & 7.8 & 23.2 & 15.6 & 7.6 \\
\hline Rs & O-5 & 28.6 & 14.1 & 14.5 & 31.4 & 16.2 & 15.2 \\
\hline & $10-15$ & 23.2 & 14.2 & 9.0 & 24.1 & 14.9 & 9.2 \\
\hline & $20-25$ & 22.5 & 13.9 & 8.6 & 23.6 & 15.5 & 8.1 \\
\hline $\mathrm{Gm}$ & O-5 & 27.4 & 15.6 & 11.8 & 29.7 & 17.5 & 12.2 \\
\hline & $10-15$ & 22.4 & 14.1 & 8.3 & 24.8 & 16.3 & 8.5 \\
\hline & $20-25$ & 24.4 & 15.5 & 8.9 & 24.4 & 15.1 & 9.3 \\
\hline $\mathrm{Cp}$ & $0-5$ & 29.6 & 15.5 & 14.1 & 30.6 & 16.0 & 14.6 \\
\hline & $10-15$ & 25.4 & 15.3 & 10.1 & 25.2 & 15.3 & 9.9 \\
\hline & $20-25$ & 24.9 & 16.6 & 8.3 & 24.1 & 15.3 & 8.8 \\
\hline $\mathrm{Cd}$ & 005 & 26.8 & 13.9 & 12.9 & 29.3 & 15.6 & 13.7 \\
\hline & $10^{-15}$ & 24.6 & 15.4 & 9.2 & 25.6 & 16.1 & 9.5 \\
\hline & $20-25$ & 24.9 & 15.8 & 9.1 & 24.6 & 15.1 & 9.5 \\
\hline
\end{tabular}


and decreasing it at WP and ultimately led to the maximum increase of SAW among the plots. The SAW of 14 to $15 \%$ is acceptable to overcome the water stress problem in the terrace soil and can save a significant amount of irrigation water in the rabi season.

The impact of application of organic residues in increasing moisture holding capacity of soil was limited to the upper $10 \mathrm{~cm}$ depth. This is due to incorporation of organic residues into the maximum depth of $10 \mathrm{~cm}$. Measure should therefore be taken for deep-tilling the land and incorporating the organic residues to the deeper horizon of at least $50 \mathrm{~cm}$ to attain the water storage capacity of $100 \mathrm{~mm}$.

\section{Soil compaction and porosity}

Soil compaction and porosity were evaluated by the determination of bulk density and three-phase distribution. Data relating to them is presented in Table 7. Inconsistent values were found in different years and no gradual decrease or increase of them with time was observed. For the convenience of discussion, the data of 1990 and 1991 representing the good and bad land preparation, respectively, was shown in Table 7.

The bulk density and solid phase of the original surface soil were $1.46 \mathrm{~g} / \mathrm{cm}^{3}$ and $56.4 \%$ by volume, respectively (Table 2), which were higher than the allowable levels of $1.40 \mathrm{~g} / \mathrm{cm}^{3}$ and $52-54 \%$. By virtue of ploughing the land, lower bulk density and solid phase were always recorded in the surface layer of all the plots. In 1990, bulk density and solid phase of the surface layer in Mo plot were reduced to $1.38 \mathrm{~g} / \mathrm{cm}^{3}$ and $53.3 \%$, respectively, confirming the contribution of ploughing to attain the bulk density below $1.40 \mathrm{~g} / \mathrm{cm}^{3}$. Although the contribution of organic residues was minimum, a distinct reduction in bulk density and solid phase was observed. Minimum bulk density of 1.20 and $1.23 \mathrm{~g} / \mathrm{cm}^{3}$ was recorded in $\mathrm{Gm}$ and $\mathrm{Cp}$ plots, respectively, having the lower solid phase of 46.3 and $47.5 \%$, which was 13 and $11 \%$ lower than the bulk density in Mo plot and 18 and 16\% lower than that in the original soil. The bulk density as recorded in Rs and Cd plots was 1.31 and $1.33 \mathrm{~g} / \mathrm{cm}^{3}$, respectively, which was lower than the value in Mo but higher than those in $\mathrm{Gm}$ and $\mathrm{Cp}$ plots.

In 1991, soil compaction increased in all the plots. Maximum bulk density and solid phase of $1.41 \mathrm{~g} / \mathrm{cm}^{3}$ and $54.0 \%$, respectively, were recorded in Mo plot which were a little over the allowable value. Thus the quality of land preparation is an important factor to govern the physical properties of soil. Minimum bulk density of 1.28 and 1 . $30 \mathrm{~g} / \mathrm{cm}^{3}$ was recorded in $\mathrm{Cp}$ and $\mathrm{Gm}$ plots, respectively. These values were higher than the values in the preceding year but still lower than the allowable value of 1.40 $\mathrm{g} / \mathrm{cm}^{3}$.

There was observed no impact of organic residues on reducing soil compaction of subsurface layers. The bulk density was mostly above $1.55 \mathrm{~g} / \mathrm{cm}^{3}$ having the solid phase of above $60 \%$. Higher compaction in the subsurface layers is due to frequent use of heavy machines taking care of only the upper 5-10 cm layer. These machines would make the unploughed subsurface more compact and impervious than it was before.

The intensity of soil compaction was reflected in soil porosity and higher porosity was recorded in the surface ploughed layer (Table 7). In both 1990 and 1991, the lowest porosity of 46.7 and $46.0 \%$ was recorded in Mo plot. In 1990, the highest 
Table 7. Bulk density and three-phase distribution of the soil under application of different organic residues.

\begin{tabular}{|c|c|c|c|c|c|}
\hline \multirow{2}{*}{$\begin{array}{c}\text { Treatment } \\
\& \text { depth }(\mathrm{cm})\end{array}$} & \multirow{2}{*}{$\begin{array}{l}\text { Bulk density } \\
\qquad\left(\mathrm{g} / \mathrm{cm}^{3}\right)\end{array}$} & \multirow{2}{*}{$\begin{array}{l}\text { Particle densityl } \\
\mid \quad\left(\mathrm{g} / \mathrm{cm}^{3}\right)\end{array}$} & \multicolumn{3}{|c|}{ Three-phase distribution (vol. \%) } \\
\hline & & & Solid & Liquid & Gas \\
\hline \multicolumn{6}{|c|}{ Feb. 1990} \\
\hline Mo 0-5 & 1.38 & 2.59 & 53.3 & 18.0 & 28.7 \\
\hline $10-15$ & 1.58 & 2.59 & 61.0 & 38.0 & 1.0 \\
\hline 20-25 & 1.54 & 2.68 & 57.5 & 36.0 & 6.5 \\
\hline Rs $0-5$ & 1.31 & 2.59 & 50.6 & 17.0 & 32.4 \\
\hline $10-15$ & 1.58 & 2.59 & 61.0 & 35.0 & 4.0 \\
\hline $20-25$ & 1.57 & 2.68 & 58.6 & 37.0 & 4.4 \\
\hline $\mathrm{Gm} \mathrm{O-5}$ & 1.20 & 2.59 & 46.3 & 20.0 & 33.7 \\
\hline $10-15$ & 1.49 & 2.59 & 57.5 & 39.0 & 3.5 \\
\hline $20-25$ & 1.51 & 2.68 & 56.3 & 37.0 & 6.7 \\
\hline $\mathrm{Cp} \quad 0^{-} 5$ & 1.23 & 2.59 & 47.5 & 17.0 & 35.5 \\
\hline $10-15$ & 1.47 & 2.59 & 56.8 & 37.0 & 6.2 \\
\hline 20-25 & 1.63 & 2.68 & 60.8 & 34.0 & 5.2 \\
\hline $\mathrm{Cd} \quad \mathrm{O}-5$ & 1.33 & 2.59 & 51.4 & 19.0 & 29.6 \\
\hline 10-15 & 1.62 & 2.59 & 62.5 & 35.0 & 2.5 \\
\hline $20-25$ & 1.64 & $\begin{array}{l}2.68 \\
\text { Feb. } 1991\end{array}$ & 61.2 & 35.0 & 3.8 \\
\hline Mo $0-5$ & 1.41 & 2.61 & 54.0 & 19.0 & 27.0 \\
\hline 10-15 & 1.54 & 2.65 & 58.1 & 26.0 & 15.9 \\
\hline $20-25$ & 1.62 & 2.67 & 60.7 & 35.0 & 4.3 \\
\hline $\mathrm{Rs} \quad \mathrm{O}-5$ & 1.35 & 2.60 & 51.9 & 21.0 & 27.1 \\
\hline $10-15$ & 1.58 & 2.66 & 59.4 & 28.0 & 12.6 \\
\hline $20-25$ & 1.63 & 2.67 & 61.0 & 34.0 & 5.0 \\
\hline Gm O-5 & 1.30 & 2.59 & 50.2 & 18.0 & 31.8 \\
\hline $10-15$ & 1.49 & 2.65 & 56.2 & 32.0 & 11.8 \\
\hline $20-25$ & 1.66 & 2.65 & 62.6 & 34.0 & 3.4 \\
\hline $\mathrm{Cp} \quad 0^{-5}$ & 1.28 & 2.59 & 49.4 & 22.0 & 28.6 \\
\hline 10-15 & 1.50 & 2.65 & 56.6 & 31.0 & 12.4 \\
\hline $20-25$ & 1.60 & 2.67 & 59.9 & 35.0 & 5.1 \\
\hline $\mathrm{Cd} \quad 0-5$ & 1.36 & 2.59 & 52.5 & 23.0 & 24.5 \\
\hline 10-15 & 1.56 & 2.66 & 58.6 & 32.0 & 9.4 \\
\hline $20-25$ & 1.64 & 2.65 & 61.9 & 36.0 & 2.1 \\
\hline
\end{tabular}

porosity of 53.7 and $52.5 \%$ was recorded in $\mathrm{Gm}$ and $\mathrm{Cp}$ plots, respectively, which was 15 and 12\% higher than the porosity in Mo plot. In 1991, the highest porosity of 50.6 and $49.8 \%$ was recorded in $\mathrm{Cp}$ and $\mathrm{Gm}$ plots, respectively, which was 10 and $8 \%$ higher than that in Mo plot. As the samples were collected in the rabi season, high gaseous phase of more than $25 \%$ prevailed in the surface layer, indicating good aeration exceeding the acceptable value of $20 \%$. In the subsurface layers the soil was compact and had minimum porosity. The porosity of subsurface layers remained mostly below $42 \%$ and most of them was occupied by water maintaining the anaerobic condition.

Soil compaction and porosity were rather strongly influenced by ploughing. In addition, rice cultivation probably destroyed soil structures and pores during puddling for transplantation. None the less, organic residues had a positive and distinct impact 
on the improvement of those properties. However, such impact was restricted to the surface 5 to $10 \mathrm{~cm}$ layer under the present land preparation, leaving subsurface layers compact. This is not benefit to wheat and other deep-rooted upland crops. Deep -tilling along with incorporation of organic residues is desirable.

\section{Drainage condition}

Drainage condition was evaluated by measuring the infiltration rate of water in the field and saturated hydraulic conductivity (HC) in the laboratory. Table 8 shows the data on infiltration rate of water under different treatments of organic residues for a total period of $300 \mathrm{~min}$. Since there was no systematic change in infiltration rate with year, the data of 1991 and 1992 was listed here for evaluation.

An impact of organic residues on increasing infiltration rate was noticed only in the first $20 \mathrm{~min}(\mathrm{O}-10$ and $10-20 \mathrm{~min})$ of infiltration. In both years the lowest infiltration rates $(2.8$ and $1.5 \mathrm{~mm} / \mathrm{min}$ in 1991 and 2.3 and $1.8 \mathrm{~mm} / \mathrm{min}$ in 1992) were recorded in Mo plot. The highest rates of 3.6 and $2.3 \mathrm{~mm} / \mathrm{min}$ in 1991 and 3.2 and $2.2 \mathrm{~mm} / \mathrm{min}$ in 1992 were recorded in Cp plot. After $20 \mathrm{~min}$ the infiltration rate approached the same value in all the plots irrespective of application or kinds of organic residues, suggesting the attainment of infiltrated water to the compact subsurface layer. The infiltration rate dropped abruptly after $30 \mathrm{~min}$ and then further decreased gradually having the very low steady-state infiltration rate of 0.08 to 0.13 (1991) and 0.03 to 0.08 (1992) $\mathrm{mm} / \mathrm{min}$.

Data on saturated HC is presented in Table 9. The saturated HC was directly related to soil compaction. As a result relatively higher $\mathrm{HC}$ was recorded in the ploughed surface layer and the quite low values of $\mathrm{HC}$ were noted in the compact subsurface layers. In both years of 1991 and 1992, effect of organic residues on increasing the $\mathrm{HC}$ in the surface layer was more or less clearly observed. Among the plots, relatively higher $\mathrm{HC}$ was recorded in $\mathrm{Cp}\left(2.2\right.$ to $\left.8.7 \times 10^{-3} \mathrm{~cm} / \mathrm{s}\right)$ and Rs (3.8 to 7.1 $\times 10^{-3} \mathrm{~cm} / \mathrm{s}$ ) plots, comparable with the result of infiltration study. They were higher by about one order than the $\mathrm{HC}$ of Mo plot which was in the order of $10^{-4} \mathrm{~cm} / \mathrm{s}$. In the subsurface layers, the $\mathrm{HC}$ was very low, ranging from $6.1 \times 10^{-6}$ to $1.7 \times 10^{-8} \mathrm{~cm} / \mathrm{s}$, even in the organic-residue treated plots, indicating the poor drainage condition.

Table 8. Infiltration rate of water $(\mathrm{mm} / \mathrm{min})$ of the soil under application of different organic residues.

\begin{tabular}{c|l|ll|llll|l|l|l}
\hline & \multicolumn{9}{|c}{ Feb. 1991 } & \multicolumn{1}{c}{ Mar. 1992 } \\
Time (min) & M & Rs & Gm & Cp & Cd & Mo & Rs & Gm & Cp & Cd \\
\hline $0-10$ & 2.8 & 3.5 & 3.2 & 3.6 & 3.4 & 2.3 & 2.7 & 2.9 & 3.2 & 2.8 \\
$10-20$ & 1.5 & 2.1 & 1.9 & 2.3 & 1.8 & 1.8 & 2.1 & 1.8 & 2.2 & 2.0 \\
$20-30$ & 1.1 & 1.3 & 1.0 & 1.2 & 1.0 & 1.4 & 1.7 & 1.2 & 1.6 & 1.6 \\
$30-60$ & 0.7 & 0.6 & 0.6 & 0.5 & 0.6 & 1.0 & 0.9 & 0.6 & 1.0 & 0.6 \\
$60-90$ & 0.4 & 0.5 & 0.5 & 0.4 & 0.4 & 0.5 & 0.5 & 0.5 & 0.5 & 0.4 \\
$90-120$ & 0.3 & 0.4 & 0.3 & 0.4 & 0.3 & 0.4 & 0.3 & 0.4 & 0.4 & 0.3 \\
$120-150$ & 0.3 & 0.3 & 0.7 & 0.2 & 0.2 & 0.2 & 0.2 & 0.3 & 0.3 & 0.2 \\
$150-180$ & 0.2 & 0.2 & 0.2 & 0.2 & 0.2 & 0.1 & 0.1 & 0.2 & 0.2 & 0.2 \\
$180-240$ & 0.2 & 0.1 & 0.2 & 0.1 & 0.1 & 0.1 & 0.1 & 0.1 & 0.1 & 0.1 \\
$240-300$ & 0.1 & 0.1 & 0.1 & 0.1 & 0.1 & 0.0 & 0.1 & 0.1 & 0.1 & 0.1 \\
\hline
\end{tabular}


Table 9. Saturated hydraulic conductivity $(\mathrm{cm} / \mathrm{s})$ of the soil under application of different organic residues.

\begin{tabular}{cc|ccc|c}
\hline Soil depth (cm) & Mo & Rs & Gm & CP & Cd \\
\hline \multicolumn{6}{c}{ Feb. 1991} \\
$0-5$ & $4.9 \times 10^{-4}$ & $7.1 \times 10^{-3}$ & $8.4 \times 10^{-4}$ & $2.2 \times 10^{-3}$ & $9.3 \times 10^{-4}$ \\
$10-15$ & $6.1 \times 10^{-6}$ & $4.8 \times 10^{-7}$ & $3.1 \times 10^{-7}$ & $5.4 \times 10^{-6}$ & $6.8 \times 10^{-7}$ \\
$20-25$ & $3.3 \times 10^{-7}$ & $5.6 \times 10^{-7}$ & $3.7 \times 10^{-8}$ & $1.7 \times 10^{-8}$ & $2.7 \times 10^{-7}$ \\
$0-5$ & $2.1 \times 10^{-4}$ & $3.8 \times 10^{-3}$ & $1.3 \times 10^{-3}$ & $8.7 \times 10^{-3}$ & $1.1 \times 10^{-3}$ \\
$10-15$ & $3.8 \times 10^{-8}$ & $4.3 \times 10^{-7}$ & $2.8 \times 10^{-6}$ & $1.2 \times 10^{-7}$ & $4.0 \times 10^{-7}$ \\
$20-25$ & $1.6 \times 10^{-7}$ & $2.2 \times 10^{-8}$ & $5.1 \times 10^{-7}$ & $5.3 \times 10^{-7}$ & $2.8 \times 10^{-8}$ \\
\hline
\end{tabular}

Based on the above information, drainage condition of the surface layer was surely improved by application of organic residues. From the viewpoint of the cultivation of upland crops, however, improvement of drainage condition of the whole soil profile is much required. If water can not drain down the profile, improving only the upper shallow layer would be of no use. High intensity of rainfall will bring the soil quickly under saturation and create anaerobic condition. Under this circumstance, deep -tilling along with incorporation of organic residues is essential to improve soil physical conditions. In this case, prevention of excess evaporation through soil surface becomes a new problem to be solved.

\section{Grain yield of crops}

Rice

Table 10 shows the grain yield of rice under different treatments of organic residues and $\mathrm{N}$. The main effect of organic residues on grain yield of rice was significant in each year with the exception of the 1st year of 1988 when the highest yield of $2.20 \mathrm{Mg} / \mathrm{ha}$ was recorded in Mo plot. Probably the 1st application of organic residues was not enough to create immediate impact on yield or even made an adverse effect on the growth of rice seedlings. From the second year the lowest yield of 2.08 to $3.25 \mathrm{Mg} /$ ha was always recorded in Mo plot. In 1989 , the highest yield (2.81 Mg/ ha) was recorded in $\mathrm{Cp}$ plot which was $35 \%$ higher than that in Moplot. The yields in $\mathrm{Rs}, \mathrm{Gm}$, and Cd plots were 24, 10, and 12\% lower than the yield in Cp plot. During the remaining four years the yield in $\mathrm{Cp}$ plot was not the highest, but it was very close to the highest yield and there was no significant yield difference between these two plots. In 1990 and 1993, the highest yield of 3.21 and $3.09 \mathrm{Mg} / \mathrm{ha}$, respectively, was recorded in $\mathrm{Cd}$ plot which was closely followed by $\mathrm{Cp}$ plot. The yield in $\mathrm{Cp}$ plot was 3.17 and $3.02 \mathrm{Mg} /$ ha in those two years. In 1991 and 1992, the highest yield of 4.39 and 4.37 Mg/ha, respectively, was recorded in $\mathrm{Gm}$ plot. The 2nd highest yield in these respective years was also recorded in $\mathrm{Cp}$ plot which was 4.22 and $4.02 \mathrm{Mg} / \mathrm{ha}$. These results indicate that higher and stable yield of rice is expected by using compost. Compost can be considered as the best organic residue. The other organic residues like cowdung and ipilipil leaves favour yield of rice as well, but the performance is less stable and is considered as next to compost. Rice yield in Rs plot did not increase significantly with respect to Mo in five out of six years. This is due to the lower supply of $\mathrm{N}$ from the rice straw as stated in total $\mathrm{N}$ content of soil and most of the $\mathrm{N}$ 
being used by soil microorganisms instead of crops.

The impact of $\mathrm{N}$ on yield of rice was significant in each year and the yield increased with the increasing amount of applied N (Table 10). In 1988 to 1990, the yield in NO plot was in the range of 1.03 to $1.88 \mathrm{Mg} / \mathrm{ha}$. The highest yield was recorded in $\mathrm{N} 2$ plot with the range of 2.61 to $3.58 \mathrm{Mg} /$ ha having an increase of 153 to 90\% compared with NO. The yield in 1991 and 1992 was higher in all the plots. The yield in NO plot was $3.32 \mathrm{Mg} /$ ha in both the years. The highest yield of 4.34 and 4.12 $\mathrm{Mg} /$ ha was recorded in $\mathrm{N} 2$ plot in those two years having an increase of 31 and $24 \%$ compared with NO. The yield under N1 was slightly lower than that under N2 but there was no significant difference between them. In 1993, the yield in NO and N2 plots was 2.47 and $3.42 \mathrm{Mg} / \mathrm{ha}$, respectively. The yield in $\mathrm{N} 2$ plot was $38 \%$ higher than that in NO plot. From the above information, it reveals that in terrace soil highest yield of rice can be assured by application of $\mathrm{N}$ at the rate of $100 \mathrm{~kg} / \mathrm{ha}$. But, continuous application of organic residues reduces the requirement of $\mathrm{N}$-fertilizer as

Table 10. Grain yield of rice $(\mathrm{Mg} / \mathrm{ha})$ in six consecutive years as affected by application of organic residues and nitrogen.

\begin{tabular}{|c|c|c|c|c|c|c|}
\hline Treatment & 1988 & 1989 & 1990 & 1991 & 1992 & 1993 \\
\hline \multicolumn{7}{|c|}{ Organic residues } \\
\hline Mo & 2.20 & $2.08 \mathrm{c}$ & $2.28 \mathrm{~b}$ & $3.10 \mathrm{C}$ & $3.25 \mathrm{c}$ & $2.75 b$ \\
\hline Rs & 1.88 & $2.13 \mathrm{c}$ & $2.49 \mathrm{~b}$ & $3.83 \mathrm{~b}$ & $3.72 \mathrm{bc}$ & $2.79 \mathrm{~b}$ \\
\hline $\mathrm{Gm}$ & 1.78 & $2.54 \mathrm{~b}$ & $2.42 \mathrm{~b}$ & $4.39 \mathrm{a}$ & $4.37 \mathrm{a}$ & $3.01 \mathrm{ab}$ \\
\hline $\mathrm{CP}$ & 1.97 & $2.81 \mathrm{a}$ & $3.17 \mathrm{a}$ & $4.22 \mathrm{ab}$ & $4.02 \mathrm{ab}$ & $3.02 \mathrm{ab}$ \\
\hline $\mathrm{Cd}$ & 1.99 & $2.47 \mathrm{~b}$ & $3.21 \mathrm{a}$ & $3.95 \mathrm{~b}$ & $3.81 \mathrm{ab}$ & $3.09 \mathrm{a}$ \\
\hline$P$ & NS & 0.01 & 0.01 & 0.01 & 0.01 & 0.05 \\
\hline \multicolumn{7}{|l|}{ Nitrogen } \\
\hline NO & $1.03 \mathrm{~b}$ & $1.81 \mathrm{c}$ & $1.88 \mathrm{c}$ & $3.32 \mathrm{~b}$ & $3.32 \mathrm{~b}$ & $2.47 \mathrm{C}$ \\
\hline N1 & $2.24 \mathrm{a}$ & $2.57 \mathrm{~b}$ & $2.68 \mathrm{~b}$ & $4.03 \mathrm{a}$ & $4.07 \mathrm{a}$ & $2.90 \mathrm{~b}$ \\
\hline $\mathrm{N} 2$ & $2.61 \mathrm{a}$ & $2.84 \mathrm{a}$ & $3.58 \mathrm{a}$ & $4.34 \mathrm{a}$ & $4.12 \mathrm{a}$ & $3.42 \mathrm{a}$ \\
\hline$P$ & 0.01 & 0.01 & 0.01 & 0.01 & 0.01 & 0.01 \\
\hline \multicolumn{7}{|c|}{ Organic residues $\mathrm{x}$ Nitrogen } \\
\hline MoNO & 1.77 & $1.61 \mathrm{i}$ & $1.59 \mathrm{~g}$ & 2.57 & 3.03 & 2.38 \\
\hline $\mathrm{N} 1$ & 2.25 & $2.16 \mathrm{~g}$ & $2.18 \mathrm{def}$ & 3.09 & 3.00 & 2.58 \\
\hline N2 & 2.58 & $2.46 \mathrm{ef}$ & $3.06 \mathrm{bc}$ & 3.64 & 3.72 & 3.28 \\
\hline Rs NO & 0.63 & $1.57 \mathrm{i}$ & $1.72 \mathrm{fg}$ & 3.67 & 2.97 & 2.32 \\
\hline N1 & 2.42 & $2.22 \mathrm{~g}$ & $2.63 \mathrm{~cd}$ & 3.79 & 3.88 & 2.93 \\
\hline $\mathrm{N} 2$ & 2.60 & $2.59 \mathrm{de}$ & $3.12 \mathrm{~b}$ & 4.02 & 4.32 & 3.13 \\
\hline Gm NO & 0.57 & $1.83 \mathrm{~h}$ & $1.78 \mathrm{fg}$ & 3.64 & 3.82 & 2.64 \\
\hline N1 & 2.19 & $2.82 \mathrm{bc}$ & $2.39 \mathrm{de}$ & 4.58 & 4.88 & 3.02 \\
\hline $\mathrm{N} 2$ & 2.57 & $2.98 \mathrm{~b}$ & $3.09 \mathrm{bc}$ & 4.94 & 4.41 & 3.38 \\
\hline Cp NO & 1.17 & $2.29 \mathrm{fg}$ & $2.16 \mathrm{def}$ & 3.50 & 3.75 & 2.45 \\
\hline N1 & 2.24 & $2.93 \mathrm{~b}$ & $3.11 \mathrm{bc}$ & 4.55 & 4.28 & 3.12 \\
\hline $\mathrm{N} 2$ & 2.49 & $3.21 \mathrm{a}$ & $4.23 \mathrm{a}$ & 4.61 & 4.03 & 3.48 \\
\hline $\mathrm{Cd} \mathrm{NO}$ & 1.03 & $1.74 \mathrm{hi}$ & $2.13 \mathrm{ef}$ & 3.21 & 3.03 & 2.58 \\
\hline N1 & 2.11 & $2.70 \mathrm{~cd}$ & $3.09 \mathrm{bc}$ & 4.16 & 4.29 & 2.87 \\
\hline $\mathrm{N} 2$ & 2.82 & $2.96 \mathrm{~b}$ & $4.40 \mathrm{a}$ & 4.48 & 4.10 & 3.83 \\
\hline$P$ & NS & 0.05 & 0.01 & NS & NS & NS \\
\hline
\end{tabular}

In a column followed by the same letter(s) is not significantly different. 
was found in 1991 and 1992 when the rice yield in NO plot was as high as 76 and 81\%, respectively, of the yield in $\mathrm{N} 2$ plot and there was no significant yield difference between $\mathrm{N} 1$ and $\mathrm{N} 2$ plots.

Data on the combined effects of organic residues and $\mathrm{N}$ on the yield of rice is included in Table 10. There was no interaction effects of organic residues and $\mathrm{N}$ on rice yield in 1988, 1991, 1992, and 1993. In 1988, the first application of organic residues could not create any impact on yield of rice, but in 1989 and 1990, application of organic residues in cooperation with $\mathrm{N}$-fertilizer created significant impact on increasing rice yield. From 1991 and onward, the effect of organic residues and N -fertilizer became fixed and limited to the individual influence on rice yield. In 1988, the first year of the experiment, the overall yield performance was poor. Relatively better yield of $1.77 \mathrm{Mg}$ /ha was recorded in MoN0 plot. In 1989 and 1990, poor yield of 1.61 and $1.59 \mathrm{Mg} /$ ha, respectively, was recorded in MoN0 plot. In 1989, the highest yield of $3.21 \mathrm{Mg} / \mathrm{ha}$ was recorded in $\mathrm{CpN} 2$ plot. The 2nd and 3rd highest yields of 2.98 and $2.96 \mathrm{Mg} / \mathrm{ha}$ were recorded in $\mathrm{GmN} 2$ and $\mathrm{CdN} 2$ plots. The yield difference of $\mathrm{CpN} 2, \mathrm{GmN} 2$ and $\mathrm{CdN} 2$ with respect to $\mathrm{MoN} 0$ was 99,85 , and $84 \%$, respectively. In 1990, the highest yield of $4.40 \mathrm{Mg} / \mathrm{ha}$ was recorded in CdN2 plot which was closely followed by $\mathrm{CpN} 2(4.23 \mathrm{Mg} / \mathrm{ha})$ plot and there was no significant yield difference between the two plots.

In 1991 and 1992, the yield of rice was higher in all the plots. The yield in MoN0 plot in these two consecutive years was 2.57 and $3.03 \mathrm{Mg} / \mathrm{ha}$. In 1991, the highest yield of $4.94 \mathrm{Mg} / \mathrm{ha}$ was recorded in GmN2 plot which was followed by $\mathrm{CpN} 2(4.61 \mathrm{Mg} / \mathrm{ha})$ plot. The yield in $\mathrm{GmN} 1(4.58 \mathrm{Mg} / \mathrm{ha})$ and $\mathrm{CpN} 1(4.55 \mathrm{Mg} / \mathrm{ha})$ plots was also appreciably high. In 1992, the highest yield of $4.88 \mathrm{Mg} /$ ha was recorded in GmN1 plot. The yield in $\mathrm{CpN} 1(4.28 \mathrm{Mg} / \mathrm{ha})$ and $\mathrm{CdN} 1(4.29 \mathrm{Mg} / \mathrm{ha}$ ) was also high. In those two years organic residues dominated in producing satisfactory higher yield even under reduced application rate of inorganic $\mathrm{N}$. The supply of $\mathrm{N}$ from organic residues favoured increased yield of rice under $\mathrm{N} 1$ level. In 1993, the yield in MoN0 plot was $2.38 \mathrm{Mg} / \mathrm{ha}$. The highest yield of $3.83 \mathrm{Mg} / \mathrm{ha}$ was recorded in CdN2 plot with the 2nd highest yield of $3.48 \mathrm{Mg} /$ ha in $\mathrm{CpN} 2$ plot.

From the above information, it can be inferred that both organic residues and $\mathrm{N}$ contributed to yield increase in rice. Compost along with $\mathrm{N}$ application at the rate of $100 \mathrm{~kg} / \mathrm{ha}$ produced stable and higher yield of rice in each year. The impact of cowdung and ipilipil leaves was less stable and can be graded next to compost. Continuous application of organic residues often relieved the higher rate of application of inorganic $\mathrm{N}$ and produced satisfactory higher yield of rice by applying $\mathrm{N}$ at the rate of $75 \mathrm{~kg} / \mathrm{ha}$. Thus a substantial amount of costly $\mathrm{N}$-fertilizer can be saved by poor farmers by applying relatively cheaper organic residues which is superior to inorganic fertilizer in improving soil physical properties as well.

\section{Wheat}

Table 11 shows the grain yield of wheat under different treatments of organic residues and $\mathrm{N}$. The main effect of organic residues on grain yield of wheat was significant every year, thereby exhibiting importance of organic residues in increasing the yield of wheat. During all the five years the lowest yield of 1.00 to $1.57 \mathrm{Mg} / \mathrm{ha}$ was recorded in Mo plot. Among the organic-residue treated plots, best performance was 
Table 11. Grain yield of wheat (Mg/ha) in five consecutive years as affected by application of organic residues and nitrogen.

\begin{tabular}{|c|c|c|c|c|c|}
\hline Treatment & 1988 & 1989 & 1990 & 1991 & 1992 \\
\hline \multicolumn{6}{|c|}{ Organic residues } \\
\hline Mo & $1.52 \mathrm{~b}$ & $1.31 \mathrm{~d}$ & $1.57 \mathrm{~d}$ & $1.00 \mathrm{~d}$ & $1.33 \mathrm{~b}$ \\
\hline Rs & $1.84 \mathrm{~b}$ & $1.57 \mathrm{c}$ & $1.98 \mathrm{~cd}$ & $1.75 \mathrm{~b}$ & $2.48 \mathrm{a}$ \\
\hline $\mathrm{Gm}$ & $1.85 \mathrm{~b}$ & $1.66 \mathrm{bc}$ & $2.19 \mathrm{bc}$ & $1.50 \mathrm{c}$ & $1.98 \mathrm{ab}$ \\
\hline $\mathrm{CP}$ & $2.10 \mathrm{a}$ & $1.83 \mathrm{ab}$ & $2.98 \mathrm{a}$ & $1.98 \mathrm{a}$ & $2.62 \mathrm{a}$ \\
\hline $\mathrm{Cd}$ & $2.00 \mathrm{ab}$ & $1.93 \mathrm{a}$ & $2.57 \mathrm{ab}$ & $1.92 \mathrm{ab}$ & $2.20 \mathrm{ab}$ \\
\hline$P$ & 0.05 & 0.01 & 0.01 & 0.01 & 0.01 \\
\hline \multicolumn{6}{|l|}{ Nitrogen } \\
\hline NO & $0.56 \mathrm{~b}$ & $0.50 \mathrm{c}$ & $1.10 \mathrm{c}$ & $0.36 \mathrm{c}$ & $0.84 \mathrm{~b}$ \\
\hline N1 & $2.41 \mathrm{a}$ & $2.02 \mathrm{~b}$ & $2.49 \mathrm{~b}$ & $2.02 \mathrm{~b}$ & $2.54 \mathrm{a}$ \\
\hline $\mathrm{N} 2$ & $2.66 \mathrm{a}$ & $2.47 \mathrm{a}$ & $3.17 \mathrm{a}$ & $2.51 \mathrm{a}$ & $2.98 \mathrm{a}$ \\
\hline$P$ & 0.01 & 0.01 & 0.01 & 0.01 & 0.01 \\
\hline \multicolumn{6}{|c|}{ Organic residues $\mathrm{x}$ Nitrogen } \\
\hline Mo NO & 0.35 & $0.30 \mathrm{i}$ & $0.49 \mathrm{~h}$ & $0.22 \mathrm{~g}$ & 0.77 \\
\hline N1 & 1.73 & $1.59 \mathrm{f}$ & 1.71 ef & $1.25 \mathrm{f}$ & 1.30 \\
\hline $\mathrm{N} 2$ & 2.47 & $2.05 \mathrm{de}$ & $2.52 \mathrm{~cd}$ & $1.54 \mathrm{ef}$ & 1.91 \\
\hline Rs NO & 0.49 & $0.41 \mathrm{hi}$ & $1.07 \mathrm{gh}$ & $0.36 \mathrm{~g}$ & 0.89 \\
\hline N1 & 2.41 & $1.90 \mathrm{e}$ & $2.19 \mathrm{de}$ & $2.19 \mathrm{~cd}$ & 3.27 \\
\hline $\mathrm{N} 2$ & 2.62 & $2.41 \mathrm{~b}$ & $2.68 \mathrm{~cd}$ & $2.70 \mathrm{ab}$ & $3.2 \%$ \\
\hline Gm NO & 0.75 & $0.58 \mathrm{gh}$ & $1.28 \mathrm{fg}$ & $0.30 \mathrm{~g}$ & 0.74 \\
\hline $\mathrm{N} 1$ & 2.21 & $2.05 \mathrm{de}$ & $2.50 \mathrm{~cd}$ & $1.83 \mathrm{de}$ & 2.38 \\
\hline $\mathrm{N} 2$ & 2.58 & $2.35 \mathrm{bc}$ & $2.78 \mathrm{~cd}$ & $2.37 \mathrm{bc}$ & 2.82 \\
\hline $\mathrm{Cp} \quad \mathrm{NO}$ & 0.67 & $0.65 \mathrm{~g}$ & $1.47 \mathrm{fg}$ & $0.49 \mathrm{~g}$ & 1.04 \\
\hline $\mathrm{N} 1$ & 2.85 & $2.15 \mathrm{~cd}$ & $3.05 \mathrm{bc}$ & $2.41 \mathrm{bc}$ & 2.87 \\
\hline $\mathrm{N} 2$ & 2.77 & $2.68 \mathrm{a}$ & $4.41 \mathrm{a}$ & $3.05 \mathrm{a}$ & 3.94 \\
\hline $\mathrm{Cd}$ NO & 0.54 & $0.56 \mathrm{gh}$ & $1.20 \mathrm{fg}$ & $0.44 \mathrm{~g}$ & 0.77 \\
\hline $\mathrm{N} 1$ & 2.86 & $2.39 \mathrm{~b}$ & $3.02 \mathrm{bc}$ & $2.42 \mathrm{bc}$ & 2.87 \\
\hline $\mathrm{N} 2$ & 2.84 & $2.85 \mathrm{a}$ & $3.48 \mathrm{~b}$ & $2.89 \mathrm{a}$ & 2.96 \\
\hline$P$ & $N S$ & 0.05 & 0.05 & 0.01 & NS \\
\hline
\end{tabular}

In a column followed by the same letter(s) is not significantly different.

exhibited by $\mathrm{Cp}$ plot giving the highest yield in four years and the 2 nd highest in one year of 1989 . The yield ranged from 1.83 to $2.98 \mathrm{Mg} /$ ha which was 40 to $90 \%$ higher than that in Mo. The yield in $\mathrm{Cd}$ plot was next to that in $\mathrm{Cp}$ plot giving the highest yield in one year (1989) and the 2nd highest during the rest of the years. From these results, it reveals that even with the early application of organic residues at 5 to 6 months before wheat sowing, wheat yield was favoured by application of organic residues in this clayey soil of the terrace area. Among the organic residues, $\mathrm{Cp}$ was found to be the best followed by $\mathrm{Cd}$ and $\mathrm{Rs}$.

The impact of $\mathrm{N}$ on the yield of wheat was significant (Table 11). Wheat yield was increased linearly with amount of $\mathrm{N}$ applied in each year. The yield in NO plot was excessively low and was within the range of $0.36 \mathrm{Mg} / \mathrm{ha}$ in 1991 and $1.10 \mathrm{Mg} / \mathrm{ha}$ in 1990. Yield as recorded in $\mathrm{N} 2$ plot was $2.51 \mathrm{Mg} / \mathrm{ha}$ in 1991 and $3.17 \mathrm{Mg} / \mathrm{ha}$ in 1990. Yield difference between NO and N2 plots in those two years was 597 and 188\%. It means that $\mathrm{N}$ application is very effective in increasing yield of wheat. The organic 
residues applied at 5 to 6 months earlier could not play a major role in increasing wheat yield and as such the contribution of $\mathrm{N}$ was the maximum. Comparatively poor yield of wheat with respect to rice may be mainly due to poor soil fertility. Rice yield was favoured by addition of organic residues, which was mostly exhausted before wheat cultivation.

As for the combined effects of organic residues and $\mathrm{N}$, the yield in MoN0 plot was found to be the lowest in each year and remained in the range of 0.22 to $0.77 \mathrm{Mg} / \mathrm{ha}$. In 1988, three plots (CdN1, CpN1, and CdN2) approached to attain the highest yield of wheat. The yield as recorded was $2.86,2.85$, and $2.84 \mathrm{Mg} / \mathrm{ha}$, respectively. In 1989 , the highest yield of $2.85 \mathrm{Mg} / \mathrm{ha}$ was recorded in CdN2 plot which was closely followed by $\mathrm{CpN} 2(2.68 \mathrm{Mg} / \mathrm{ha})$ plot. Yield difference of these two high yielding plots with respect to MoN0 plot was as much as 850 and $793 \%$, respectively. In 1990, 1991, and 1992, the highest yield was recorded in $\mathrm{CpN} 2$ plot and it was $4.41,3.05$, and $3.94 \mathrm{Mg}$ / ha. These results indicate that both organic residues and $\mathrm{N}$ have contributed to increase wheat yield and that the contribution of $\mathrm{N}$ application was higher. The best combination of organic residues and $\mathrm{N}$ for increasing wheat yield was the compost with $\mathrm{N}$ application at the rate of $120 \mathrm{~kg} / \mathrm{ha}$.

\section{SUMMARY AND CONCLUSIONS}

The terrace soil has poor chemical and physical properties. High acidity, low organic matter and total $\mathrm{N}$ contents, low moisture holding capacity, high soil compaction, and poor aeration and drainage conditions are the major constraints to the cultivation of upland crops.

Under the present application rate of organic residues, the equilibrium level of organic matter content in the surface soil was increased from 7 to $9-10 \mathrm{~g} / \mathrm{kg}$. After each addition of organic residues the organic matter content increased considerably, but at the end of each year of application it came down close to the equilibrium level.

Incorporation of organic residues led to the improvement of physical properties in the surface layer. The soil available water of only $10 \%$ in the original soil was remarkably increased up to $15 \%$ by applying organic residues, which is acceptable for saving irrigation water in the rabi season. Organic residues caused minimum improvement of soil compaction, porosity and drainage condition of the surface ploughed layer, because these properties were greatly influenced by the depth of ploughing and hampered significantly by rice cultivation and use of heavy machines.

Application of organic residues has resulted in increasing grain yield of rice and wheat. The effect of $\mathrm{Cp}$ (compost) treatment was found to be superior in increasing yield of those two crops. The impact of $\mathrm{Cd}$ (cowdung) and $\mathrm{Gm}$ (ipilipil leaves) treatments was next to $\mathrm{Cp}$. The highest level of $\mathrm{N}$ application in wheat $(120 \mathrm{~kg} / \mathrm{ha})$ was effective in obtaining the highest yield, but in rice medium application of $\mathrm{N}(75 \mathrm{~kg} /$ ha) often gave the highest yield or close to the highest yield obtained by applying 100 $\mathrm{kg} / \mathrm{ha}$, indicating the reduction in $\mathrm{N}$-fertilizer requirement of the crop by application of organic residues.

Based on the results of six consecutive years, the following conclusions can be drawn : (a) compost is the most effective organic residue in improving soil properties 
and increasing yield of rice and wheat ; (b) organic residues remarkably improved the physical and chemical properties but restricted to the ploughed surface layer ; (c) yield of wheat was much affected by the $\mathrm{N}$ level, and effect of organic residues was relatively large in rice yield ; and (d) best combination of organic residues and $\mathrm{N}$ for increasing yield of rice and wheat was the compost with the application of 75 and 120 $\mathrm{kg} \mathrm{N} / \mathrm{ha}$, respectively.

\section{REFERENCES}

Blake, G. R. 1965 Particle density. In "Methods of Soil Analysis" Part 1, ed. by C. A. Black, American Society of Agronomy, Inc., Madison, Wisconsin, USA, pp. 371-375

Bouyoucos, G. J. 1927 The hydrometer as a new method for the mechanical analysis of soils. Soil Sci., $23: 343-353$

Bremner, J. M. 1965 Total nitrogen. I n "Methods of Soil Analysis" Part 2, ed. by C. A. Black, American Society of Agronomy, Inc., Madison, Wisconsin, USA, pp. 1149-1178

Ganai, B. A. and C. M. Singh 1988 Effect of farmyard manure applied in rice-wheat rotation on physico-chemical properties of soil. Indian J. Agronomy, 33 : 327-329

Greenland, D. J. 1988 Soil organic matter in relation to crop nutrition and management. In "Proceedings of the International Conference on the Management and Fertilization of Upland Soils in the Tropics and Subtropics, 1986", Nanjing, China

Jackson, M. L. 1958 Soil Chemical Analysis. Constable Co. Ltd., London

Karim, Z., S. M. Rahman, M. Idris and A. J. M. S. Karim 1988 Field capacity. In "A Mannual for the Determination of Soil Physical Properties", Soils \& Irrigation Division, Bangladesh Agricultural Research Council, Dhaka, Bangladesh

Karim, A. J. M. S., K. Egashira, S. M. Saheed and M. H. R. Biswas 1994 Evaluation of physico -chemical properties of terrace soils of Bangladesh in relation to crop production. Bull. Inst. Trop.Agr., Kyushu Univ., in press

Piper, C. S. 1942 Soil and Plant Analysis. Interscience, New York, pp. 221-222

Rabindra, B., G. V. Narayanawamy, N. A. Janardhan and Shivanagappa 1985 Long range effect of manures and fertilizers on soil physical properties and yield of sugarcane. J. Indian Soil Sci., 33 : 704-706

Sherma, S. K., C. M. Sherma and I. S. Chakor 1988 Effect of industrial organic wastes and latena incorporation on soil properties and yield of rice. Indian J. Agron. 32: 225-226 